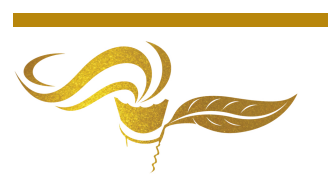

\title{
A Note on Transdisciplinary Thinking -Meaning Making is an Art-
}

\section{Raymond T. Yeh}

City of Ten Thusand Buddhas, 2001 Talmage Road, Ukiah, CA 95482, Email:raytyeh@gmail.com Received 17 December, 2020; Revised 30 December, 2020; Accepted 31 December, 2020

Available online 1 January, 2021 at www.atlas-journal.org, doi: 10.22545/2021/00144

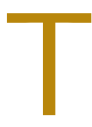

his article is a follow up on an earlier article ${ }^{1}$ in an effort to tackle complex problems: be it economic, social, environmental, etc. by utilizing different examples to explore a transdisciplinary methodological framework based on an interpretation of how Leonardo da Vinci tackled tough problems in his time. ${ }^{2}$ The subtitle is a tribute to da Vinci in that he always tried to depict his understandings of nature in art forms. Our interpretation of da Vinci's approach is summarized into four words, namely: transcendence, possibility, leveraging, and mastery which we will elaborate below.

Keywords: Transdisciplinary, self-limiting assumption, transcendence, possibility, leveraging, mastery.

\section{Introduction}

\section{Disciplinary thinking is often self-limiting}

Many years ago, I did a workshop for some 50 corporate managers in which I asked them to draw a self-portrait on a large piece of paper. We then had an art show of these self-portraits. Afterwards, about $85 \%$ of the people also identified with one portrait during our art show as shown in Figure 1.

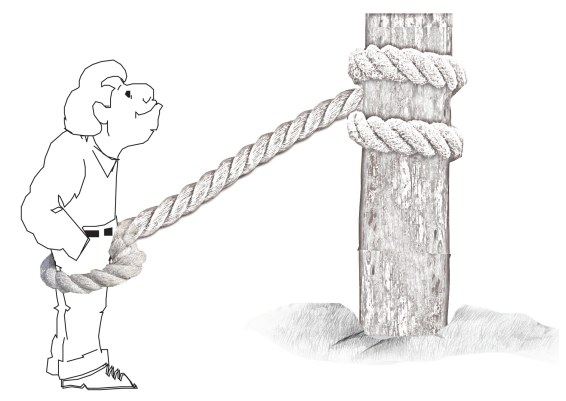

Figure 1: Person tied to a post.

The above figure basically says that the person is tied to a post. Well, almost everyone in the workshop identified with this picture though tied to different posts such as family, location, job etc. Each such factor

\footnotetext{
${ }^{1}$ Raymond T. Yeh, (2019). Towards a Framework for Transdisciplinary problem solving. Transdisciplinary Journal of Engineering \& Science, Vol. 10, pp. 26-34.

${ }^{2}$ Fritjof Capra,(2013). Learning From LEONARDO. Berrett-Koehler Publishers, Inc. San Francisco.
} 
is what I called a self-limiting assumption (SLA). Indeed, almost all of us have $S L A$ s. An interesting example is that of Napoleon. The American engineer, Robert Fulton, who was the inventor of the steam powered ships that sailed the Mississippi River. When Fulton tried to convince Napoleon that he could defeat the British Navy by using steam powered ships. Napoleon disconnected and told Mr. Fulton that "What? sail upstream against the wind with a fire under my decks? I have no time for such nonsense." 3 Well, Napoleon's self-limiting view, as an Army general, costed him the opportunity to beat the British Navy.

Consider the story about Charles Darwin and his friend John Gould, a prominent ornithologist. When Darwin returned from his 5-year trip to study geology, he gave his collection of poorly labelled birds, finches, wrens, blackbirds as well as mockingbirds from Galapagos Islands to John Gould, as an expert taxonomist. Gould quickly identified that there were 13 varieties and each variety represented a distinct species, probably one from each of the 13 major islands of the Galapagos Islands. The results confused Darwin. For example, the beaks of finches were used for different functions as some were better to crack nuts while others for pecking insects. While Gould was able to quickly identified the distinct varieties of the birds, it was Darwin to raise the question: "is it possible for a species of birds to split into two or more species if the birds were isolated on separate islands?" 4 This question eventually led Darwin to the discovery of the Theory of Evolution! The gist of the above stories indicated the limiting aspect of any disciplinary thinking as both Napoleon and John Gould demonstrated.

A fundamental aspect of TD-thinking is to break the SLAs in order to create new meanings as Lao Tze said well below:

"The mark of a moderate man

Is freedom from his own ideas...

Nothing is impossible for him...

Because he has let go..."

\section{Learning from Leonardo da Vinci}

"One who does not respect life does not deserve it!"

- Leonardo da Vinci -

The above quote pretty much described the essence of this pioneering transdisciplinarian who played different roles: as an artist, scientist, engineer, as well as an eco-designer, in order to understand the nature of life. As Prof. Fritjof Capra elegantly described that "his science is a science of living forms, and his art served this persistent quest for life's inner secrets. In order to paint nature's living forms, Leonardo felt he needed both a scientific understanding of their intrinsic nature and underlying principles in order to analyze the results of his observations as well as his artistic ability to depict them. I believe that this intersection of needs is the very essence of his synthesis of science and art" 5

Based on Dr. Capra's work, I've deduced a framework of Leonardo's work with four concepts as outlined below:

1. Transcendence: As a consequence of his deep quest to understand the nature of life. I believe that Leonardo's consciousness level was raised in accordance with his insights obtained from the various projects he worked on which provided inspirations for his other projects. Recall the previous story of Darwin, here is a piece from his autobiography:

\footnotetext{
${ }^{3}$ Robert S. Block, "Everything is connected to Everything Else", Private communication.

${ }^{4}$ Frans Johansson, The MEDICI EFFECT, Harvard Business School Press, 2004.

${ }^{5}$ Fritjof Capra, Learning From LEONARDO, Berrett-Koehler Publishers, Inc. San Francisco, 2013.
} 
"In October 1838, that is, fifteen months after I had begun my systematic inquiry, I happened to read for amusement 'Malthus on Population,' and being well prepared to appreciate the struggle for existence which everywhere goes on from long-continued observation of the habits of animals and plants, it at once struck me that under these circumstances favorable variations would tend to be preserved, and unfavorable ones to be destroyed. The result of this would be the formation of new species. Here then I had at last got a theory by which to work." 6

The above insight, triggered by some reading for amusement, seemed to inspire Darwin into a higher level of consciousness and set a clear direction in his research direction.

2. Possibility: According to Capra, Leonardo's work has always been putting life at the center of his work in recognition of the fact that "all-natural phenomena are fundamentally interconnected and interdependent".

By embracing an "interconnected worldview" of seeing nature as a model and mentor. Leonardo was able to see new possibilities previously hidden. This network concept is very similar to the modern notion of system thinking ${ }^{7}$ which began with the study of cybernetics about patterns of life leading eventually to ecological studies of not only nature but also human society with the associated social, economic, environmental concerns etc. Pattern is the result of ordered relationships within an organization or environment. As such, systemic properties are properties of a pattern. For example, the culture of an organization is one of its key patterns. Therefore, when a small company is merged into a big one, its cultural pattern is usually destroyed over time while many other components such as buildings, people, etc. may remain.

3. Leveraging: Many meaningful connections of ideas for innovation came to view as he tried "to understand a phenomenon meant connecting it with other phenomena through a similarity of patterns".

This concept is most associated with many modern notions of innovation. Consider the former Apple CEO Steve Jobs with his iPod - cited as one of the best examples of innovation.

Well, the iPod wasn't the first portable music device (Sony popularized the "music anywhere, anytime" concept more than 20 years earlier with its Walkman); iPod wasn't the first device that put hundreds of songs in your pocket (dozens of manufacturers had MP3 devices on the market when the iPod was released in 2001); and Apple was actually late to the party when it came to providing an online music-sharing platform. (Napster, Grokster and Kazaa all preceded iTunes.)

What made the iPod and the music ecosystem it engendered was that it meaningfully leveraged all of these elements into a well-designed (enhanced ergonomics and ease of use) single device, and then tied it into a platform that effortlessly kept that device updated with music. Apple invented nothing. Its innovation created an easy-to-use ecosystem that unified music discovery and delivery in a single device. And, in the process, it revolutionized the music industry.

iPod is a good illustration of oft quoted phrase of Archimedes:

\section{"Give me a lever long enough and a place to stand,} and I will move the earth."

Leveraging on different components via meaningful connections for innovation has been widely used in many fields. More than 20 years ago, my good friend, Dr. Stephen Hochshuler, founder of the Texas Back Institute, showed me one of the key aspects of his institute's practice during a visit to him. Every morning, the doctors will gather together to review some of the more difficult cases together, leveraging on each other's experience and knowledge. Stephen is a pioneer in the modern notion of

\footnotetext{
${ }^{6}$ Murray Francis (ed). The life and letters of Charles Darwin (p. 83). London, 1887.

${ }^{7}$ Fritjof Capra, The Web of Life, Anchor Books, Doubleday, 1996.
} 
precision medicine. Stephen's approach was similar to NASA-JPL's X-team approach that I also witnessed at the same time framework.

Here is a wonderful architectural example of building an office compound in Zimbabwe with no air conditioning system-a great challenge as the temperature in the African plains can range from 40 degrees at night to over 100 during the day. However, Mike Pearce, architect for the Eastgate Center in Harare, the capital of Zimbabwe, accomplished the mission by basing his design on how termites cool their mounds of mud and dirt. Eastgate, a huge office complex, was able to maintain its temperature between 73-77 degrees. ${ }^{8}$ Like Leonardo, Pearce's new architectural design derived from the process of nature.

Another wonderful example of leveraging came from Dr. Clair Brown, a renowned professor of economics at the University of California at Berkeley, who leveraged Buddhist mindset for some of the toughest economic problems of our time. In her book "Buddhist Economics: An enlightened approach to the dismal science" ${ }^{9}$ which provided an economic framework that integrates global sustainability, shared prosperity and care for the human spirit. By leveraging on Buddhist philosophy of compassion and accumulated lessons of modern economic theory, she developed a holistic approach based on actual national policies that reduce inequality, protect the environment, and Share-Prosperity Index (SSPI) for 50 countries. While it will take courage and political will to implement her suggested policy actions, many of them, however, have already been partially implemented in northern European nations as well as in Nepal, a Buddhist country.

It is interesting to note here that Leonardo's idea of "seeking for similarity of patterns" was rediscovered by Mr. Altshuller, a Russian engineer. He and his colleagues developed a problem-solving methodology called The Theory of Inventive Problem Solving (TRIZ) ${ }^{10}$ built on the study of the patterns of problems and solution using logic, data, and research ...!

4. Mastery By expanding his ability to see new connections as he usually worked on several diverse projects at the same time and when he got some insight from one project, he would also update other relevant projects. What Leonardo showed us is that the journey to mastery is never ending!

Consider the journey of athletes in the high jump competition. In the early part of 1900s, high jump record stood at just over $6 \mathrm{ft}$. By 1990, that record has been raised to over 8 feet. During this period, innovative high jumper introduced three radically different techniques, each one a vast improvement over the previous one. The last one, the Fosbury Flop ${ }^{11}$ was ridiculed by critics who felt the techniques looked sloppy and undignified. But the results are stunning. The introduction of each new technique caused the high jump world to shift to a new paradigm until it reached a plateau and gained maturity. Then, someone will come up with a new innovation for the next leap.

While the above story is an excellent example of mastery for individuals, how do we deal with truly complex issues of our time, e.g. the COVID-19 Pandemic and other important issues on social and economic policies, climate change, social inequality, etc.? In other words, how do we deal in general with the two important issues of mastery, namely; resilience and sustainability? Or if we take into considerations of ethics as in the language of ecologists, the question becomes "how can we satisfy our needs without endanger the survivability of future generations?"

In their 2002 book Cradle to Cradle: Remaking the Way We Make Things, architect William McDonough and chemist Michael Braungart presented an integration of design and science that provides enduring benefits for society from safe materials, water and energy in circular economies and eliminates the concept of waste.

\footnotetext{
${ }^{8}$ Frans Johansson, The MEDICI EFFECT, Harvard Business School Press, 2004.

${ }^{9}$ Clair Brown, Buddhist Economics: An enlightened approach to the dismal science (Bloomsbury Press), 2014.

${ }^{10}$ Atila Ertas, Transdisciplinary Engineering Design Process, John Wiley \& Sons, 2018.

${ }^{11}$ The person jumps backwards over the bar with the legs following the upper body. It is named after the US athlete Dick Fosbury who first used this method at the 1968 Olympics and won a gold medal.
} 
The book put forward a design framework characterized by the key principle of Zero Waste derived from nature. Indeed, in nature, the "waste" of one system becomes food for another. Everything can be designed to be disassembled and safely returned to the soil as biological nutrients, or re-utilized as high-quality materials for new products as technical nutrients without contamination.

Rather than seeking to minimize the harm we inflict, Cradle to Cradle re-frames design as a positive, regenerative force-one that creates footprints to delight in. This paradigm shift reveals opportunities to improve quality, increase value and spur innovation. It inspires us to constantly seek improvement in our designs.

\section{Examples to Interpret the Methodological Framework}

In the following, we shall provide some examples to interpret the methodological framework mentioned above.

\section{The story of North Hawaii Community Hospital (NHCH $)^{12}$}

Located in the northwest town of Waimoa on the island of Hawaii and serving only 30,000 residents, the hospital nevertheless has developed an international reputation. For example, one Japanese cancer patient who could hardly speak English insisted on being treated at NHCH.

$\mathrm{NHCH}$ is yet another dream come true for Earl Bakken, co-founder of Medtronic, who has long dreamed of a hospital that blended Eastern and Western healing approaches for the benefit of patients. At $\mathrm{NHCH}$, patients are usually under the care of Western physicians, but are free to request the acupuncture and energy healing treatments offered by the Eastern-trained or Hawaiian professionals at the hospital. While the local population and state officials doubted that $\mathrm{NHCH}$ would ever open because of the difficulty in obtaining a permit, the hospital defied all odds and opened in 1996 . While Bakken is thrilled that the hospital is operational, he knew it's only the beginning. He has a bigger dream. With $\mathrm{NHCH}$, he envisioned a patient-centered, high-tech, high-touch and natural environment in which to practice "blended" or "complementary" medicine. We will provide here a simple description of the essence of NHCH design in terms of the TD-framework mentioned earlier.

Transcendence - Bakken, always fascinated with healing, seeks to bring a completely new concept of healthcare to the world, called a "Healing Island," a term he coined. Inspired by Hippocrates, the acknowledged father of Western medicine, who established a medical center and school more than 2,000 years ago on the island of Kos, located in the Aegean Sea. Bakken strives to transform the entire island of Hawaii into a vortex for healing, envisioning it as the 21st century Kos of the Pacific.

Possibility - In the case of $\mathrm{NHCH}$, its vision statement is: "our vision is to treat the whole individualbody, mind, and spirit-through a team approach to patient-centered care, and ultimately to become the most healing hospital in the world." As an example of the above statement, NHCH is located in the middle of 5 volcanos, benefiting from their collective energy.

Leveraging - Figure 2 below provides a strategy in that the design is the result of blending "high tech", "high-touch" and "ideal environment". While we will not get into the specific "high tech" equipment here, we note that the notion of "high touch" used in the Figure 2 has a specific denotation at NHCH. For example, in addition to the traditional physician-patient relationship, the hospital uses the primary nursing concept, which assigns a single nurse to a group of patients rather than having different nurses perform separate functions. With primary nursing, each patient has a better chance of developing a trusting relationship with their nurse. In addition, $\mathrm{NHCH}$ uses the concept of a "care team," which brings the primary nurse aides and housekeepers together in groups of five to care for groups of eight patients. This facilitates closer relationships between the hospital staff and patients. It's concept of an "ideal environment" will be described more in the section below.

\footnotetext{
${ }^{12}$ Raymond Yeh and Stephanie Yeh, The Art of Business, Zero Time Publishing, 2004.
} 
Raymond T. Yeh

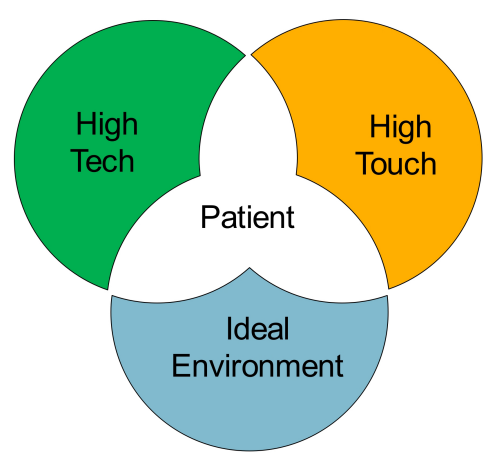

Figure 2: Strategy for blending design - "high tech", "high-touch" and "ideal environment".

Mastery- Figure 3 below provides the patient-centered model for healing. Within the model is the never-ending process of improving the notion of "patient-centered care". The Internal-ExternalPhysical-Psycho framework creates a healing presence on all relationships for healing each patient who is also a partner.

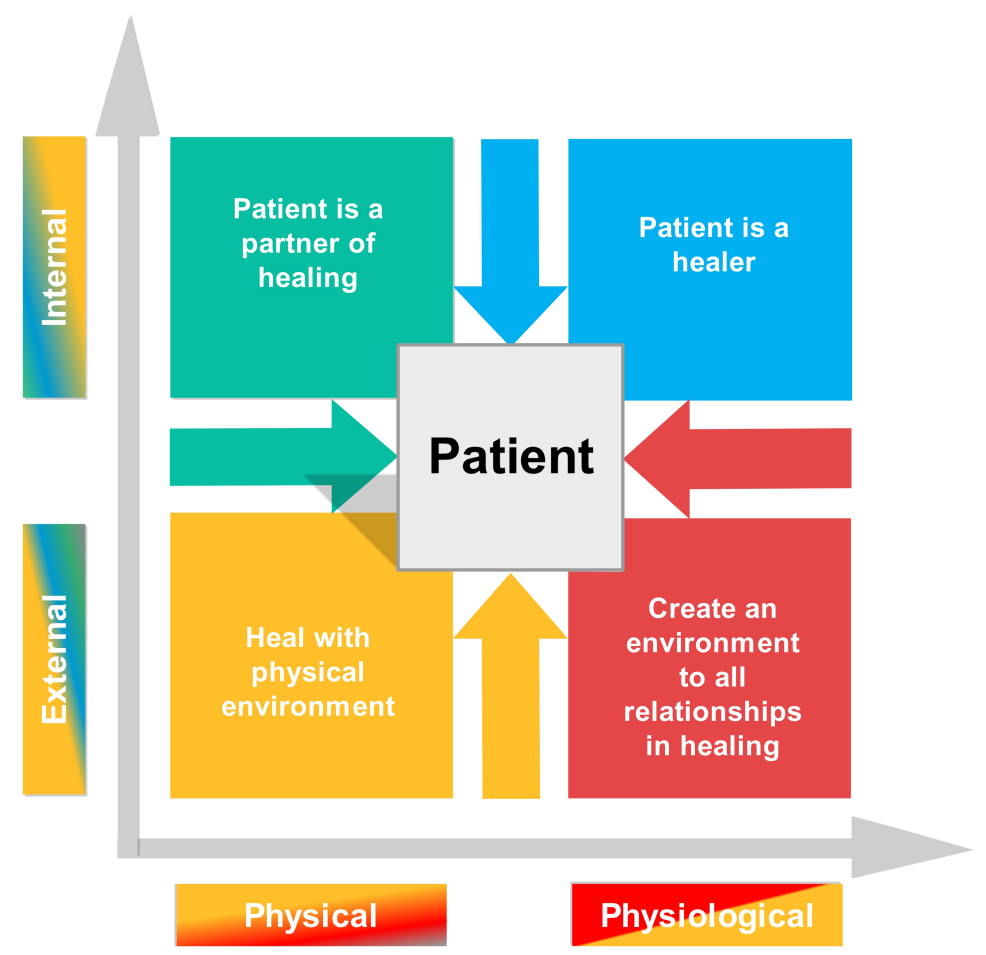

Figure 3: Patient-centered model for healing.

The vertical axis depicts the patient's environment, both internal and external, while the horizontal axis depicts the nature of the environment in terms of physical or psycho-social-spiritual aspects. For example, the first quadrant encompasses physical elements of the external environment. At $\mathrm{NHCH}$, windows are easy to open and every room has a sliding door that leads to an outside garden (the hospital is a single floor structure), which gives patients direct access to fresh air and sunshine. Skylights are scattered throughout the hospital's rooms and hallways, and the décor features pleasing 
and lively colors. Patients are encouraged to choose specific works of art for their own rooms and closed-circuit "care channels" are programmed with music and video images developed specifically for healing. NHCH offers a wide assortment of fresh foods, as well as education on diet and nutrition.

The second quadrant of the model looks at the psycho-spiritual elements in the patient's environment. For Bakken, the relationship with others or the "healing presence" is the cornerstone for this quadrant. To facilitate maximum healing, the hospital offers a wide variety of Western and Eastern healing approaches, including acupuncture and energy healing. The third quadrant deals with the patient's internal environment. Contrary to the normal traditional Western physician-patient model, at $\mathrm{NHCH}$ the patient is considered a partner in healing. The whole spectrum of wellness, including dietary habits, exercise, smoking, drinking, and drug use fits in this quadrant. Finally, the fourth quadrant addresses the psycho-spiritual aspects within a patient. In other words, what does the patient bring to the table for his or her own healing? Do they have a lot of self-love? Do they feel responsible for their life and their healing process, or do they feel like victims? This quadrant engages the healing potential within each patient, bringing it up to the conscious level to aid in the healing process.

\section{Transforming South African from Apartheid syndrome to a democratic Republic ${ }^{13}$}

On April 27, 1994, the world stood back in awe as South Africans of all races stood in long lines to cast their votes in the country's first democratic election. Prior to that election, few could imagine that South Africa, bitterly divided between white power and black oppression, would become a symbol of hope to all nations. In a miraculous moment of perfect timing, all the necessary ingredients came together for the creation of the unprecedented Truth and Reconciliation process, which featured forgiveness and reconciliation between races rather than punishment and retribution. Historically, the primarily black African National Congress (ANC) had been supported by the former Soviet Union, leading Western nations to support the opposing white apartheid forces. However, when Mikhail Gorbachev burst onto the world scene and brought the ideas of perestroika and glasnost to bear, the so-called "evil empire" of the Soviet empire began to disintegrate, along with its expansionist support of the ANC. As a result, Western nations could no longer justify supporting white apartheid South Africa. As the dominant Eastern and Western nations began to withdraw their influence from South Africa, Nelson Mandela, imprisoned leader of the ANC, and F. W. DeKlerk, leader of the white apartheid government, both rose to meet the challenge of creating a peaceful future, seizing this single cubic centimeter of chance for reconciliation. DeKlerk had tremendous difficulty in persuading the whites that it was in their best interests to lay down their arms. It required great humility for DeKlerk to fight for a democratic process that would eventually vote him out of office.

But Mandela and other black leaders had a far more difficult time taming the fire of the blacks who demanded vengeance. After 27 years of imprisonment by the white government, though, Mandela stood as the perfect icon to preach and ask for forgiveness, creating the unforgettable process of Truth and Reconciliation. Indeed, during the period between 1990, when Nelson Mandela was freed from prison and the ban was lifted on the ANC and other black and left-wing political parties, and when the first all-race election was held in 1994, a flurry of radical and miraculous events took place that helped the nation to transition away from apartheid toward freedom.

One of these events was the Mont Fleur scenario project, which was sponsored by a group of South African academics, business people, and activists. Adam Kahane was chosen from Shell's strategy department to help them facilitate the forum utilizing Shell's scenario methodology. The group intended to influence the future of the country by developing a set of scenarios that described how events might unfold over the coming ten-year period. The forum consisted of 22 leaders drawn from organizations spread across the political map, including academics, ANC members, members of the old establishment, and businessmen. "One of the good things about working with a group like this is that they can learn a lot about what is going on from listening to each other. It was as if each of them

\footnotetext{
${ }^{13}$ Adam Kahane, Solving Tough Problems, Berrett-Koehler Publishers, Inc. San Francisco. 2004.
} 
had a piece of the larger puzzle picture of South Africa." Using Shell's scenario planning method and guided by Kahane, the team came up with four scenarios:

- Ostrich: A story of the white government believing that it could avoid a negotiated settlement with the black majority, burying its head in the sand, and thereby making matters worse in the end.

- Lame Duck A story of prolonged transition where the new government was hobbled by compromises built into the constitution and, because "it purports to respond to all but satisfies none." As such, it would not be really able to address the country's problems.

- Icarus: A story describing the results of a strong black majority government coming to power on a wave of popular support and embarking on a huge, unsustainable public spending spree that would crash the economy.

- Flight of the Flamingoes: A key characteristics of flamingoes is that they take off slowly but they fly together. This scenario is a story about how the new government could avoid the pitfalls of the first three scenarios and gradually rebuild a successful economy.

According to Kahane, the Icarus scenario was the most unexpected and probably exerted the greatest influence. This scenario was created at a time when most leadership attention was focused on achieving a successful political and constitutional transition, not on economics. The Icarus scenario pointed out that the conventional tendency to redistribute resources away from rich whites to poor blacks would not create a sustainable solution for the country. Once the scenarios had been written, the team organized a series of workshops with different political, business, and civic groups, where the stories were presented and the implications discussed. Kahane recalled one particular event: "One of the workshops was with the leadership of the Pan Africans Congress (the PAC), a radical black political party, and at this meeting one of the members of the Mont Fleur team, who was the PAC's head of economics, presented the Icarus scenario. He said 'This is a story about what will happen if our rivals, the ANC, come to power. And if they don't do it, we will push them into it.' That provocation led to one of the most productive of all the workshops. Many years later, in 1999, when another member of the team was appointed to be Governor of the Reserve Bank, he said at his inauguration, "We are not Icarus. There is no need to fear that we will fly too close to the sun." Kahane believed that economic wisdom and prudence of the post - 1994 South African government has been influenced by the Mont Fleur scenarios, especially the Icarus scenario.

Below is a summary of the above narratives in terms of TD-thinking framework:

Transcendence - to see collectively the possibility beyond each participant's view to reach a solution for all. Indeed, the consciousness of the whole nation was greatly enhanced as Mandela skillfully leveraged the Rugby game to bring the consciousness of the whole nation to a high level after they won the world championship in 1995.

Possibility - scenarios took into considerations of social, political, economic and international considerations. Indeed, after the black government took over, they created the Truth and Reconciliation Commission, a court-like body established in 1995 to help heal the country and brought about a reconciliation of its people by uncovering the truth ab"The Truth Commission helped us to move away from the past to concentrate on the present and future"!

Leveraging - involving leaders from most of the key national constituencies and hence facilitated better understanding as well as embracing an interdependent world view. Also, prior to winning the World Cup, the Rugby team had travelled extensively around the country to work with teams in schools to connect on a national basis.

Mastery - The Mont Fleur project clearly made a lasting imprint on South Africa's social, political and economic transition. While the approach was basically transplanted directly from Shell's planning team, Kahane noticed that the effects were much different in South Africa. He said: "Although the 
methodology of this project was the same as the one we used at Shell, the purpose was fundamentally different. The Mont Fleur participants were not, like corporate strategists, simply trying to adapt to the future as best they could; they had come together because they wanted to influence the future, to make it better. They were playing on a larger field. When you think about it logically, at least one of the reasons the future is unpredictable is because we can influence it. The team members didn't see themselves as detached observers, but as active participants; most of them had devoted their lives to fighting for a better South Africa. They were aware of how their own thoughts and actions had an impact of what happened around them - they were reflective." In other words, mere analysis lacks the force and purpose to create a desired future. South Africa's almost unimaginable transition demonstrated that co-creating a desired future provided the inspiration which translated into passionate, active participation to serve a higher purpose.

While the use creative teamwork to identify and influence critical current choices during the workshop, it would not have been enough to change the fate of a nation. In fact, more than 100 such workshops were held later around the country to spread the message. Indeed, it was a miracle to move a nation with apartheid Syndrome to a democratic Republic by overcoming great social and economic barriers to embrace a common world view that they can fly together to create a new order!

\section{The founding and maintenance of the American Dream.}

On the night of July 2, 1776, words reached the delegates attending the Second Continental Congress in Philadelphia that the British Empire struck, intending to annihilate the budding democracy of its rebel colony. By August there were 32,000 British troops in New York, ready to march on Philadelphia, a city with a population of only 30,000. George Washington's pickup army of 7,000 untrained, ill-equipped farmers stood as the only line of resistance. Each of the delegates who signed the Declaration of Independence was fully aware of the death sentence that awaited them if their bid for freedom failed.

Transcendence: As Benjamin Franklin said so well, "We must all hang together, or most assuredly, we will hang separately." The dream of freedom, the declaration that "All men are created equal; that they are endowed by their Creator with certain inalienable rights," meant more to these men than life itself. In other words, the collective inner transcendence provides the inspiration and courage to build a new nation.

Possibility/Leveraging: Opening up the American border to allow wide divergent talents to immigrate to the US to create the opportunities for all as well as to transform the American society. Indeed, as a consequence of the new possibilities, it facilitated the connection of different cultures and talents which form the basis of American innovation in the subsequent years.

Mastery: The fight for the American dream mentioned above has been renewed time and again by the great leaders in the American history: by Abraham Lincoln during the Civil War, by Martin Luther King, Jr. in the civil rights movement, and by Lyndon Baines Johnson with his vision of a Great Society, etc. Though every fight was different, each of these leaders was guided by the dream of freedom, of creating a society in which, "all men are created equal." While there were many struggles over the years, it proved the tenacity of the new Republic both in terms of its sustainability as well as resilience time and again.

\section{Towards A Framework for TD-Thinking}

Looking at how tough problems are solved in general; I would suggest that "transcendence" is the essential aspect of any major breakthroughs. In other words, the TD-thinking is a problem-solving mythological framework based on the notion of "inner transcendence inspired outer transformations" ${ }^{1}$ as shown in Figure 4. 


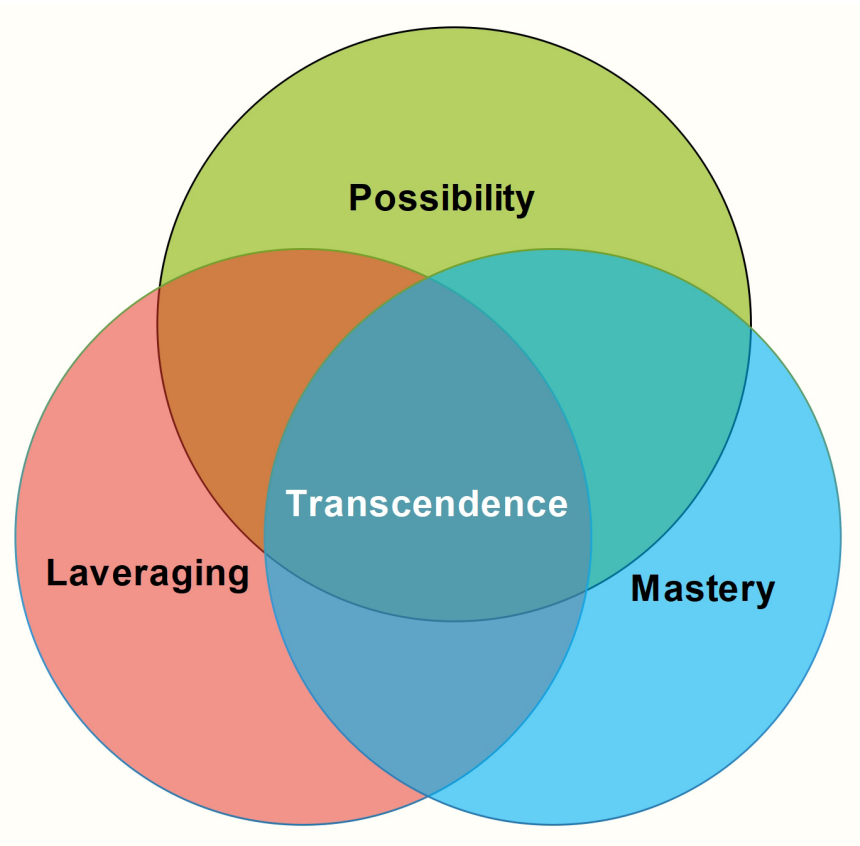

Figure 4: TD-thinking problem-solving mythological framework.

In the traditional design thinking (DT) process, ${ }^{14}$ they look for three things, namely, desirability (does this satisfy the users requirements?), feasibility (can this be done within budget/time or other constraints?) and viability (will this work for the feasible future, etc.?). The three questions above can be answered from the three outer circles of Figure 4 above from which a number of possible solutions might emerge. However, from a TD perspective, we need to answer one more question, namely, should we do this? This leads to questions such as: "should we get cheaper gas by fracking"? Should we dump millions of tons of garbage or plastics into the ocean, etc.? In other words, the question is whether it is ethical to do this no matter how profitable it is? Indeed, if our consciousness level has reached certain level to embrace that "we are all interconnected" so that if we do something, its ripple effect over time may not be so desirable to our grandchildren. Indeed, these questions lead us to discover an important aspect that traditional Design thinking does not ask the question: "what's our responsibility?" By adding this element to the Design Thinking process seems to provide a target for TD-thinking as shown in Figure 5. In other words, Figure 5 is the desirable outcome of the actions taken based on the outline in Figure 4.

It should be noted, however, that ethical consideration is not the only element of responsibility. Here is a beautiful story. ${ }^{15}$ In the middle of the 19the century, Sir Gilbert Scott was hired by the New College at the Oxford university, built in the late 14th century, to restore the roof and the great oak beams, which was badly rotten, that supported it. Representatives from the college took Sir Gilbert to visit the Great Hall Woods in Berkshire. Well, the replacements were standing there waiting to be hewn out of the living oaks trees, planted a century before, for just that purpose. A responsible leader's promise had been fulfilled!

Figure 5 has two interesting perspectives, namely, the solution of a design may vary with time as the consciousness level of the designed team or organization changes as illustrated by the example of the evolution of the United States above. This should come as no surprise based on the hierarchy of needs by Abraham Maslow. ${ }^{16}$ The moving up in each hierarchical level implies a "breaking of the SLA" mentioned

\footnotetext{
${ }^{14}$ Tim Brown, Design Thinking, Harvard Business Review, June 2008.

${ }^{15}$ MAX DePREE, Leadership Jazz, Dell Publishing, 1993.

${ }^{16}$ McLeod, S. A. (2020, March 20). Maslow's hierarchy of needs. Simply Psychology. https://www.simplypsychology.org/maslow.html
} 


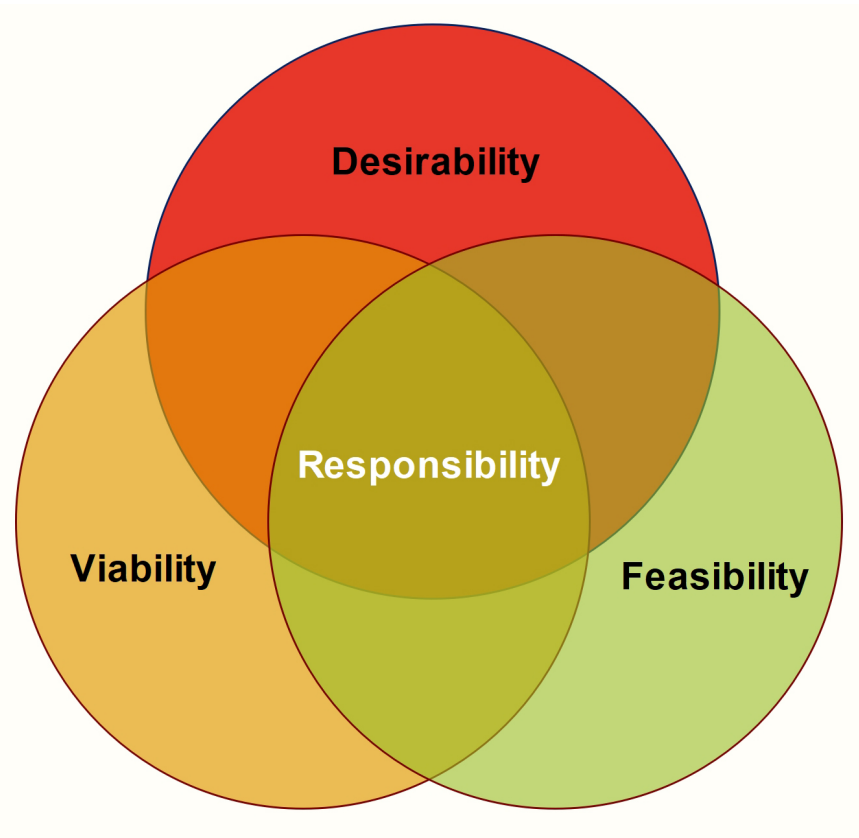

Figure 5: TD-thinking.

earlier as the foundation of DT. The story of Prof. Yunus and his Grameen bank, ${ }^{17}$ outlined in my previous paper, is a good illustration of such a behavior. It is interesting to note that Maslow had extended his initial 5-level of needs to 7 levels with the top level labeled "transcendence".

Given that the framework in Figure 5, it meshes well with the Design Thinking (DT) methodology. We also note an interesting aspect of TRIZ, mentioned earlier, in its link with the DT. The principal limitation of DT, however, is in its high subjectivity, which generates some rigidity called psychological inertia observed in the search for a solution within a very well-defined space. Also, DT does not offer strategies or techniques for the detailed solution of the intrinsic problems of the design process. This means that the procedure of the problem-solving that arises during the design process depends on the experience of a team or an individual. Thus, "TRIZ may assist the requirements of the Design Thinking model. TRIZ contains among its tools, a set of techniques that allow modeling and solving inventive problems. At the same time, TRIZ does not propose any tool or technique to identify the user's requirements, a fundamental aspect of the DT model. As a consequence, the strategy to leverage on both approaches and presents a basic structure to balance the best characteristics of both approaches has emerged". ${ }^{18}$

It is also clear that within this framework, system thinking is a natural to be deployed as part of the TD- problem- solving processes, especially for providing a holistic view of systems with long feedback loops encountered in ecological and other complex systems.

\section{Conclusion}

The core of TD thinking lies in its holistic view in tackling a problem by first surrendering to a higher purpose via transcendence in order to break SLAs of the team so that new possibilities or new connections

\footnotetext{
${ }^{17}$ Yunus, Muhammad. Banker to the Poor - Micro-lending and the Battle Against World Poverty 1999, Public Affairs, New York.

${ }^{18}$ Hugo Domingo García-Manilla etc., "Integration of Design Thinking and TRIZ Theory to Assist a User in the Formulation of an Innovation Project" in Managing Innovation in highly Restrictive Environments, Springer. International Publing AG,2019.
} 
might emerge.

The ancient Chinese general Sun Tzu understood that an ideal army must have the capability to deal with all kinds of changes, flowing like water to adapt. He asserts:

"For just as flowing water avoids the heights and hastens to the lowlands, so an army avoids strength and strikes weakness.

And as water shapes its flow in accordance with the ground.

so an army manages its victory in accordance with the situation of the enemy."

When we view an organization, such as an army, as a living organism rather than a machine, we see new possibilities. By treating organizations as machines, we see only transactions, which are the snapshots of dynamic changes occurring within and outside of the organization. However, when we shift from a mechanistic perspective to a more quantum perspective based on relationships and wholeness, we see enterprises as consisting of flows of cash, knowledge, work, material, people and information. Flows provide the links between transactions and processes, bringing an organization's environment to a dynamic, adaptable existence.

Similarly, when we view a complex problem as something solid to be decomposed into simpler pieces to be analyzed, we missed all of its intricate flows/interdependencies that constitute the whole in both space and time. Hopefully, TD-thinking, as we proposed above, provides a way to contemplate the wholeness of complex problems facing us today. Indeed, such understanding provides answers to the meaning of life - living, death, joy, sorrow, ...in the sense that we will not find it by ourselves alone, we find it with another. As we let go of our attachments, we transcend! Indeed, inner transcendence helps to inspire outer transformations!

Perhaps the following quote from Maryanne Williamson's poem is a proper place to end this article:

"And as we let our light shine,

We unconsciously give other people permission to do the same.

As we are liberated from our own fear,

Our presence automatically liberates others."

-A Return to Love -

\section{Acknowledgement}

I would like to take this opportunity to thank Prof. Atila Ertas, Prof. Yu Chen, Drs. Hsiangtao Yeh and Lily Yeh for their insightful comments!

Funding: This research article received no external funding.

Conflicts of Interest: The author declares no conflict of interest.

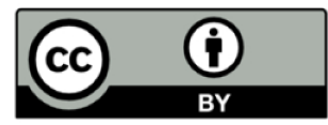

Copyright (C) 2021 by the author. This is an open access article distributed under the Creative Commons Attribution License (https://creativecommons.org/licenses/by/4.0/), which permits unrestricted use, distribution, and reproduction in any medium, provided the original work is properly cited. 


\section{About the Author}

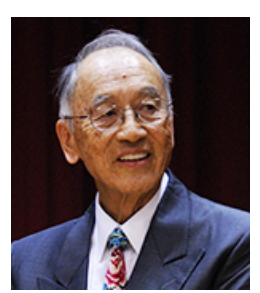

Dr. Raymond T. Yeh taught at several universities for more than 20 years and helped two Computer Science departments to top ten national rankings as chairman of department. He was also the CDC distinguished chair Professor at the University of Minnesota. He holds honorary professorship at five universities. Dr. Yeh is the founding editor-in-chief of IEEE Transanctions on Software Engineering and was on the editorial board of various journals. He also founded the Technical Committee on Software Engineering and International Conference on Software Engineering (ICSE) within the IEEE Computer Society.

Dr. Yeh co-founded two successful software companies and two professional societies. He has been a consultant to many nations including United Nations, United States, China, Japan, Singapore, Sweden, Taiwan, and works with executives of many leading edge global companies as well as with founders of start-up companies. He has published 10 technical books and coauthored two business books. Dr. Yeh is an IEEE Centennial Medal laureate, and a recipient of the Pioneer in Information Technology Award from the government of Taiwan, among others. $\mathrm{He}$ is a lifetime fellow of Institute of Electrical and Electronic Engineers (IEEE), and the Society for Design and Process Science (SDPS). Dr. Yeh had been a long term volunteer at the City of Ten Thousand Buddhas, a Buddhist monastery located in northern California since 2003. 